\title{
EFFICIENT SYNTHESIS OF BIS-(4-HYDROXYCOUMARIN) USING SULFANILIC ACID AS RECYCLABLE CATALYST IN WATER
}

\author{
Mozhgan SADAT-JALALI, ${ }^{\mathrm{a}}$ Mohammadreza MANAFI, ${ }^{\mathrm{a},}$, Seyed Saied HOMAMI, ${ }^{\mathrm{a}}$ \\ Banafsheh GORJI ${ }^{\mathrm{a}}$ and Amirhossein MONZAVI ${ }^{\mathrm{b}}$ \\ ${ }^{\mathrm{a}}$ Department of Applied Chemistry, Faculty of Science, South Tehran Branch, Islamic Azad University, Tehran, Iran \\ ${ }^{b}$ Department of Polymer and Textile Engineering, South Tehran Branch, Islamic Azad University, Tehran, Iran
}

A catalytic reaction between aromatic aldehydes and 4hydroxycoumarin has been developed to form a decent range of functionalized biscoumarin skeletons in excellent yields using sulfanilic acid as reusable catalyst in aqueous media. The catalytic reaction shows good generality and was compatible with aldehydes bearing electron-withdrawing and electron-releasing substituents. This method avoids the use of tedious work-up and column chromatographic purification of products, making the method expedient and superior. The efficient and cost-effective catalyst could be recovered and reused several times.

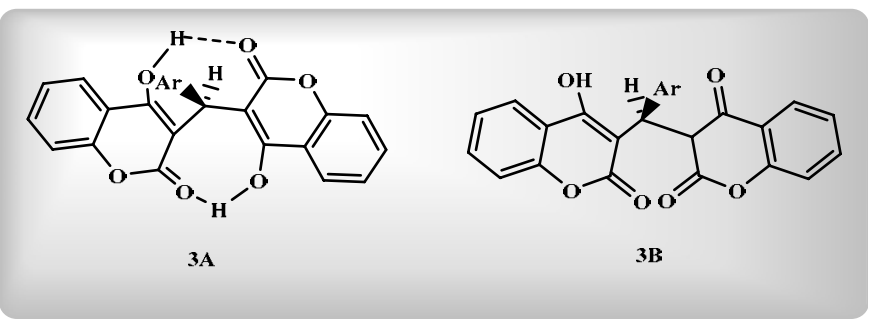

\section{INTRODUCTION}

Heterocyclic compounds are broadly found in nature and are vital to lifespan. ${ }^{1}$ Coumarins are an important class of heterocycles with diverse and interesting biological activities. ${ }^{2}$ This significance could be recognized to their broad scope of pharmaceutical and biological properties like anticoagulant, ${ }^{3}$ antibacterial, ${ }^{4}$ anti-Hepatitis $\mathrm{C}$ virus, ${ }^{5}$ antitumor, ${ }^{6}$ anticancer, ${ }^{7}$ anti-inflammatory, ${ }^{8}$ antioxidative, ${ }^{9}$ as well as antiviral, ${ }^{10}$ activities. Based on these findings, the synthesis of heterocycles bearing biscoumarin as motif will be valuable from the synthetic chemistry and biological point of view.

Numerous approaches have been recently described for the synthesis of biscoumarin derivatives with catalytic reactions based on usage of molecular iodine, ${ }^{11}$ tetrabutylammonium bromide (TBAB), ${ }^{12}$ sulfated titania, ${ }^{13}$ Sodium dodecyl sulfate(SDS), ${ }^{14}$ $\mathrm{SO}_{3} \mathrm{H}$ functionalized ionic liquids, ${ }^{15} \mathrm{Zn}$ (Proline) $)_{2},{ }^{16}$ [bmim $]\left[\mathrm{BF}_{4}\right],{ }^{17} \mathrm{RuCl}_{3} \cdot \mathrm{nH}_{2} \mathrm{O},{ }^{18} \mathrm{SiO}_{2}-\mathrm{OSO}_{3} \mathrm{H} \quad \mathrm{NPs},{ }^{19}$ $\mathrm{NaHSO}_{4} / \mathrm{SiO}_{2} /$ indion190 resin, ${ }^{20}$ choline hydroxide ${ }^{21}$ $\mathrm{CuO}-\mathrm{CeO}_{2}$ nanocomposite, ${ }^{22} \mathrm{HY}$ zeolite, ${ }^{23}$ Phthalimide-N-sulfonic, ${ }^{24}$ and ionic liquid $\left[\mathrm{Et}_{3} \mathrm{NH}\right]\left[\mathrm{HSO}_{4}\right]^{25}$ as catalyst being among the most proficient procedures.

Though these actions provide a development in the synthesis of the above stated bis-heterocyclic mixtures and their importance could not be overstated, some of them suffer from the limitations such as long reaction times, harsh reaction conditions, low yields, costly reagents, usage of organic solvents, tedious workup, and nonrecoverability of the catalyst. Consequently, the introduction of novel catalysts and approaches regarding the potential simplicity, high activity, low cost, high yields', and short reaction times, is still in request.

Based on the above literature and in continuation of our interest in the applications of reusable catalysts in organic synthesis we report 
herein a green approach for the synthesis of some biscoumarin derivatives from a reaction involving aldehydes and 4-hydroxycoumarin catalysis in sulfanilic acid (SA) in water for the first time. Water is a readily available solvent which have the advantages of being green. This solvent has been utilized as an environmentally attractive medium for some chemical transformations.

\section{RESULTS AND DISCUSSION}

The Knoevenagel-Michael type reaction for the synthesis of biscoumarins was conducted with aromatic aldehydes and 4-hydroxycoumarin in the presence of SA as catalyst (Scheme 1). SA was utilized based on its good solubility in aqueous media, offering the advantage of simple purification of the desired products from the reaction medium and additionally, found to be a good catalyst for the synthesis of biscoumarin skeletons.

The efficiency of the proposed catalytic reaction was examined with 3-nitro-benzaldehyde (1e) $(1.0 \mathrm{mmol})$ and 4-hydroxycoumarin (2) $(2.0$ mmol) under different reaction parameters and our selected results are summarized in Table 1. At the outset of our study, the reaction was examined with different amount of the catalyst (Table1, entries 1-5). A tiny increase in yield occurred in similar reaction periods upon increasing the catalyst loading (Table 1 , entry 1 vs. 2). Additionally, further increase in amounts of the catalyst resulted in completion of the desired reaction in shorter reaction times likely due to the presence of more active electrophilic species for the desired condensation reaction (Table 1, entries 3-5). However, a variation of catalyst loading of 20 $\mathrm{mol} \%$ to $25 \mathrm{~mol} \%$ did not affect the reaction outcome in appreciable manner (Table 1, entry $4 \mathrm{vs.}$ 5). Accordingly, the $10 \mathrm{~mol} \%$ catalyst loading was selected as the optimum choice based on the efficiency and cost of the catalyst (Table 1, entry 2). It is worth mentioning that the presence of catalyst is necessary for success of the transformation as in the absence of the catalyst, only traces amount of the desired product was detected in crude reaction mixture analysis even after prolonged reaction times (not shown in Table 1).

Afterwards, the effect of the reaction temperature on the reaction outcome was examined (Table 1, entries 6-12). The study indicated that decreasing the reaction temperature adversely affected the yields of the targeted product (Table 1, entries 6-10). Additionally, these reactions required longer reaction times to afford the targeted product in acceptable yields. An outcome we attributed to the lower solubility of substrates in water and the leaving group ability of $\mathrm{H}_{2} \mathrm{O}^{+}$at lower temperatures. Finally, the prototype reaction was conducted in various solvents as well as under solvent-free conditions (Table 1, entries 13-19). As shown in Table 1, the reaction was also productive in common organic solvents even at lower temperature. Additionally, the presence of solvent is vital for carrying out the transformation (Table 1, entry 19). Based on these findings, the optimal reaction conditions for this methodology were developed with a 1:2 mol ratio of benzaldehyde and 4-hydroxycoumarinin in the presence of $10 \mathrm{~mol} \%$ of $\mathrm{SA}$ as the catalyst in water at $80^{\circ} \mathrm{C}$ (Entry 2).

The generality of the transformation was then examined under the optimum conditions developed above (Table 2). 2-Chloro benzaldehyde (1a) gave the targeted product in slightly lower yields than that of 2-nitro substituted aldehyde (1b) likely due to the resonance donation nature of chloride group. It could also be deduced that the steric hindrance of substrates did not effect on the reaction outcome (Table 2, entries 1-2). Highly electron-rich substrates 1c-1d were also tolerated and afford the corresponding product in $87 \%$ and $83 \%$ yield, respectively (Table 2, entries 3-4) likely due to the electrophilicity of the substrates. 3-Nitro and 4nitrobenzaldehydes 1e-1f reacted efficiently to afford the desired compounds 3e-3f in excellent yields and short times (Table 2, entries 5-6). 4Chlorobenzaldehyde (1g) afforded a good yield (Table 2, entry 7). The tolerance for chloride offers an opportunity for subsequent cross-coupling reaction to for highly functionalized biscoumarin skeletons. As noticed, electron-rich substrates like 4-methoxybenzaldehyde (1h) or hydroxylsubstituted benzaldehydes (1i-1k) required longer reaction times to furnish the transformation with good yields (Table 2, entries 8-11). The tolerance of hydroxyl motif adds further advantage to current procedure. A modest decrease in yield occurred upon using of 2,4-dichlorobenzaldehyde (11) (Table 2 , entry 12). $p$-Tolylaldehyde (1 $\mathbf{m})$ afforded an excellent yield (Table 2, entry 13). Benzaldehyde (1n) was also good substrate in this transformation (Table 2, entry 14). By comparison, 3methoxybenzaldehyde (1p) reacted more efficiently than that of 2-methoxybenzaldehyde (1o) (Table 2, entry $16 v s .15)$. Generally speaking, aromatic aldehydes bearing electron-withdrawing groups were more reactive than those of electron-natural or electron-rich substrates. The presence of nitrile, ketone, and ester groups on aldehyde structure were not compatible with this transformation. 


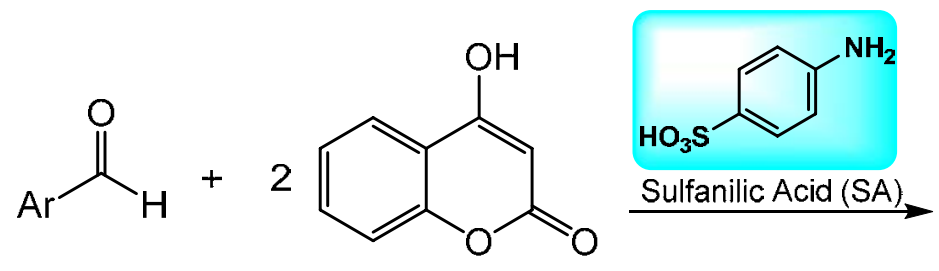

1a-p
2<smiles>O=c1oc2ccccc2c(O)c1C(Br)c1c(O)c2ccccc2oc1=O</smiles>

3a-p

Scheme 1 - Synthesis of biscoumarin.

Table 1

Optimization of the reaction conditions $3 \mathbf{e}^{\mathrm{a}}$<smiles>O=Cc1cccc([N+](=O)[O-])c1</smiles><smiles>O=c1oc2ccccc2c(O)c1C(c1cccc([N+](=O)[O-])c1)c1c(O)c2ccccc2oc1=O</smiles>

\begin{tabular}{llllll}
\multicolumn{1}{c}{$\mathbf{2}$} & & \multicolumn{2}{c}{$\mathbf{3 e}$} \\
\hline Entry & Solvent & Catalyst (mol\%) & Temp. $\left.{ }^{\circ} \mathbf{C}\right)$ & Time $^{\mathbf{b}}$ & Yield $^{\mathbf{c}}$ \\
\hline 1 & $\mathrm{H}_{2} \mathrm{O}$ & 5 & 80 & $35 \mathrm{~min}$ & 93 \\
$\mathbf{2}$ & $\mathrm{H}_{2} \mathbf{O}$ & $\mathbf{1 0}$ & $\mathbf{8 0}$ & $\mathbf{2 5} \mathbf{\text { min }}$ & $\mathbf{9 8}$ \\
3 & $\mathrm{H}_{2} \mathrm{O}$ & 15 & 80 & $24 \mathrm{~min}$ & 95 \\
4 & $\mathrm{H}_{2} \mathrm{O}$ & 20 & 80 & $22 \mathrm{~min}$ & 97 \\
5 & $\mathrm{H}_{2} \mathrm{O}$ & 25 & 80 & $21 \mathrm{~min}$ & 98 \\
6 & $\mathrm{H}_{2} \mathrm{O}$ & 10 & $\mathrm{RT}$ & $24 \mathrm{~h}$ & 51 \\
7 & $\mathrm{H}_{2} \mathrm{O}$ & 10 & 40 & $1 \mathrm{~h}$ & 63 \\
8 & $\mathrm{H}_{2} \mathrm{O}$ & 10 & 50 & $1 \mathrm{~h}$ & 67 \\
9 & $\mathrm{H}_{2} \mathrm{O}$ & 10 & 60 & $1 \mathrm{~h}$ & 81 \\
10 & $\mathrm{H}_{2} \mathrm{O}$ & 10 & 70 & $1 \mathrm{~h}$ & 93 \\
11 & $\mathrm{H}_{2} \mathrm{O}$ & 10 & 90 & $17 \mathrm{~min}$ & 87 \\
12 & $\mathrm{H}_{2} \mathrm{O}$ & 10 & 100 & $14 \mathrm{~min}$ & 96 \\
13 & EtOH & 10 & 60 & $1 \mathrm{~h}$ & 83 \\
14 & EtOH & 10 & 80 & $1 \mathrm{~h}$ & 92 \\
15 & Ethyl acetate & 10 & 80 & $1 \mathrm{~h}$ & 83 \\
16 & $\mathrm{CH}_{2} \mathrm{Cl}$ & 10 & 80 & $1 \mathrm{~h}$ & 85 \\
17 & THF & 10 & 80 & $1 \mathrm{~h}$ & 57 \\
18 & Toluene & 10 & 80 & $1 \mathrm{~h}$ & 81 \\
19 & Solvent-Free & 10 & 80 & $24 \mathrm{~h}$ & - \\
\hline
\end{tabular}

${ }^{\text {a }}$ Reaction conditions: 1e $(1.0 \mathrm{mmol}), 2(2.0 \mathrm{mmol})$, solvent $(5.0 \mathrm{~mL})$, and catalyst $(5-25 \mathrm{~mol} \%)$ at $25-100{ }^{\circ} \mathrm{C}$.

${ }^{\mathrm{b}}$ Progress of the reaction was monitored with TLC analysis. ${ }^{\mathrm{C}}$ Isolated yields.

Based on ${ }^{1} \mathrm{H}$ NMR spectra and according to the literature, ${ }^{24}$ the two coumarin fragments in 3a-p can be depicted as two-different enolic forms (Figure 1). For example, in the ${ }^{1} \mathrm{H}$ NMR spectrum of compound 3d, two singlet appeared at $\delta=11.37$ and $11.59 \mathrm{ppm}$ attributed to $\mathrm{OH}$ protons. The emergence of two distinct peaks in two separate areas suggests that the two hydroxyl groups are not equivalent, which can be attributed to two different hydrogens indicating the presence of intramolecular hydrogen bonding in the conformation 3A. Accordingly, it can be considered that the molecule adopts conformation 3A. This result is supported by X-ray crystallographic studies reported in the literature.

The recycling and reusability of the catalyst are very important for scale-up the reaction and industrial applications therefore, the recovery and reusability of SA was investigated in the reaction of 4-Nitro-benzaldehyde and 4-hydroxycoumarin under the optimum condition described in Table 1 (Table 3). Upon completion of the reaction, the catalyst was recovered after each run (see experimental section) and reused for subsequent run. The model reaction was conducted with recovered catalyst and the results indicated that the 
catalyst could be recycled five times with only a modest loss of activity. This indicated that the SA was an efficient and recyclable catalyst for the preparation of biscoumarins. It is worth mention- ing that almost all the catalyst (up to $96 \%$ ) could be recovered from each run. After the reaction has been ended, the reaction mixture was cooled to room temperature.

\section{Table 2}

Scope of the reaction with different aromatic aldehydes ${ }^{\mathrm{a}}$<smiles>[CH+]C=O</smiles><smiles>O=c1cc(O)c2ccccc2o1</smiles>

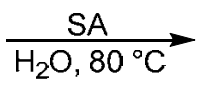<smiles>O=c1oc2ccccc2c(O)c1C(Br)c1c(O)c2ccccc2oc1=O</smiles>

\begin{tabular}{l}
\hline Entry \\
\hline 1 \\
2 \\
3 \\
4 \\
5 \\
6 \\
7 \\
8 \\
9 \\
10 \\
11 \\
12 \\
13 \\
14 \\
15 \\
16 \\
\hline
\end{tabular}

1a-p 2

3a-p

\begin{tabular}{lllll} 
Ar & Time (min.) & Product, Yield (\%) & \multicolumn{2}{c}{ Melting point } \\
\cline { 4 - 5 } & & & Found & Reported \\
\hline $2-\mathrm{Cl}-\mathrm{C}_{6} \mathrm{H}_{4}$ & 40 & $\mathbf{3 a}, 90$ & $198-200$ & $201-203^{2}$ \\
$2-\mathrm{NO}_{2}-\mathrm{C}_{6} \mathrm{H}_{4}$ & 6 & $\mathbf{3 b}, 97$ & $200-202$ & $198-200^{2}$ \\
$4-\mathrm{Me}_{2} \mathrm{~N}_{-}-\mathrm{C}_{6} \mathrm{H}_{4}$ & 23 & $\mathbf{3 c}, 87$ & $217-218$ & $221-222^{28}$ \\
$3,4-(\mathrm{MeO})_{2}-\mathrm{C}_{6} \mathrm{H}_{3}$ & 38 & $\mathbf{3 d}, 83$ & $265-266$ & $271-273^{28}$ \\
$3-\mathrm{NO}_{2}-\mathrm{C}_{6} \mathrm{H}_{4}$ & 25 & $\mathbf{3 e}, 98$ & $216-217$ & $214-215^{2}$ \\
$4-\mathrm{NO}_{2}-\mathrm{C}_{6} \mathrm{H}_{4}$ & 11 & $\mathbf{3 f}, 96$ & $233-235$ & $233-235^{2}$ \\
$4-\mathrm{Cl}-\mathrm{C}_{6} \mathrm{H}_{4}$ & 25 & $\mathbf{3 g}, 92$ & $258-260$ & $261-263^{2}$ \\
$4-\mathrm{MeO}-\mathrm{C}_{6} \mathrm{H}_{4}$ & 25 & $\mathbf{3 h}, 90$ & $253-257$ & $250-252^{2}$ \\
$2-\mathrm{OH}-\mathrm{C}_{6} \mathrm{H}_{4}$ & 28 & $\mathbf{3 i}, 81$ & $252-252$ & $254-256^{2}$ \\
$3-\mathrm{OH}-\mathrm{C}_{6} \mathrm{H}_{4}$ & 12 & $\mathbf{3 j}, 94$ & $260-262$ & $268-269^{28}$ \\
$4-\mathrm{OH}-\mathrm{C}_{6} \mathrm{H}_{4}$ & 33 & $\mathbf{3 k}, 88$ & $227-228$ & $228-231^{28}$ \\
$2,4-(\mathrm{Cl})_{2}-\mathrm{C}_{6} \mathrm{H}_{3}$ & 22 & $\mathbf{3 1}, 84$ & $198-199$ & $190-195^{4}$ \\
$4-\mathrm{Tolyl}$ & 20 & $\mathbf{3 m}, 96$ & $269-270$ & $266-270^{2}$ \\
$\mathrm{Ph}$ & 16 & $\mathbf{3 n}, 94$ & $230-232$ & $229-231^{2}$ \\
$2-\mathrm{MeO}-\mathrm{C}_{6} \mathrm{H}_{4}$ & 25 & $\mathbf{3 o}, 83$ & $212-213$ & $213-215^{14}$ \\
$3-\mathrm{MeO}-\mathrm{C}_{6} \mathrm{H}_{4}$ & 22 & $\mathbf{3 p}, 96$ & $259-260$ & $252-254^{28}$ \\
\hline
\end{tabular}

${ }^{a}$ Conditions: $1(1.0 \mathrm{mmol}), 2(2.0 \mathrm{mmol}), \mathrm{H}_{2} \mathrm{O}(5.0 \mathrm{~mL})$, and catalyst $(10 \mathrm{~mol} \%)$ at $80{ }^{\circ} \mathrm{C} .{ }^{\mathrm{b}} \mathrm{All}$ the products were characterized by ${ }^{1} \mathrm{H}-\mathrm{NMR},{ }^{13} \mathrm{C}-\mathrm{NMR}$, and IR analysis. ${ }^{\mathrm{c}}$ Isolated yield.

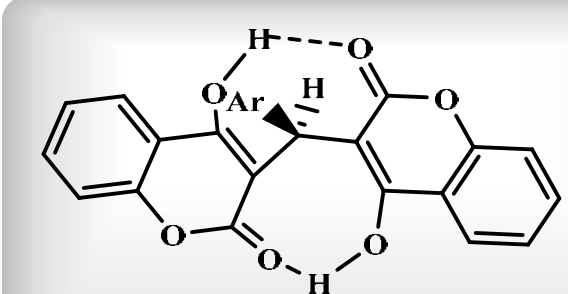

3A

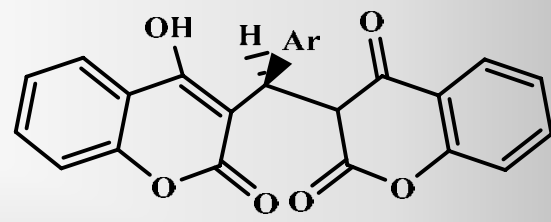

3B

Fig. 1 - Two conformations of 3

Table 3

Reusability of SA in $\mathbf{3} \mathbf{e}^{\mathrm{a}}$

\begin{tabular}{llllll}
\hline Catalyst recycle & Fresh & Run1 & Run2 & Run3 & Run4 \\
\hline Time/min & 25 & 30 & 40 & 55 & 80 \\
Isolated yield\% & 98 & 93 & 87 & 80 & 70 \\
\hline
\end{tabular}

${ }^{a}$ The reaction conditions are similar to the optimized conditions described in Table 1. 
a)

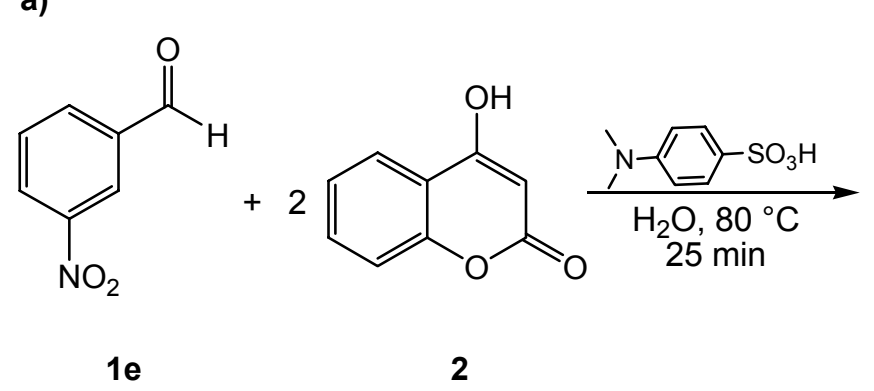<smiles>O=c1oc2ccccc2c(O)c1C(c1cccc([N+](=O)[O-])c1)c1c(O)c2ccccc2oc1=O</smiles>

3e, $97 \%$

b)<smiles>CC1CO1</smiles>

4
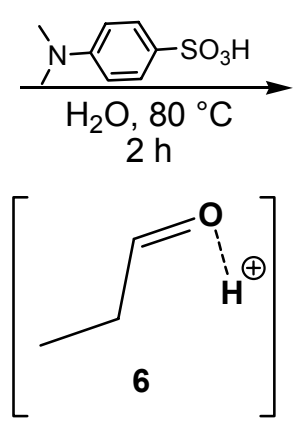<smiles>CCC(c1c(O)c2ccccc2oc1=O)c1c(O)c2ccccc2oc1=O</smiles>

5, $78 \%$

Scheme 2 - Control experiment.

In all cases, the biscoumarin synthons were isolated with a high degree of purity. If necessary, crude products can be recrystallized from the aqueous ethanol or a mixture of hexane and ethanol. The products were characterized with ${ }^{1} \mathrm{H}$ NMR, ${ }^{13} \mathrm{C}$ NMR, and physical constant. Physical and spectral data of recognized mixtures are in line with those described in the earlier studies.

To get a better insight on reaction mechanism, some control experiment were conduct (Scheme 2). To examine if the amine motif in SA is involved in reaction progress through formation of corresponding iminium salt of aldehyde, the reaction was conducted with 4-(dimethylamino)benzenesulfonic acid. As shown in Scheme 2 (part a), the reaction afforded the desired product $\mathbf{3 e}$ in almost similar yield of that SA. It could be deduced that the reaction did not proceed through an iminium salt. It should be noted that the reaction was not productive using aliphatic aldehyde likes acetaldehyde and propionaldehyde as aldehyde source. The reaction was also conducted with methyl oxirane (4) to explore the reactivity of oxirane source in this transformation (Scheme 2, part b). The reaction afforded the desired product 5 in $78 \%$ yield. It could be deduced that the reaction procceded through the attack of $\mathbf{2}$ on intermediate
6 which is probably formed via Meinwald rearrangement in the presence of SA. ${ }^{26}$

A reasonable mechanism supported by literature ${ }^{27,28}$ can be suggested for the formation of 3,3'-arylmethylene-bis(4-hydroxycoumarins)

(Scheme 3). Initially, 4-hydroxycoumarin (2) attacks on activated aldehyde $\mathbf{2}$ by the action of SA to form intermediate 7 which is then converted to the unsaturated intermediate $\mathbf{8}$ through elimination of water. Subsequently, the second molecule of 4hydroxycoumarin reacted with $\mathbf{8}$ through a Michael type reaction to give species 9 which is further tautomerizes to the desired product $\mathbf{3}$ in the presence of SA.

In order to show the merit of the present work in comparison with recently published procedures, we compared the results of the reaction of 3-nitrobenzaldehydes $(1.0 \mathrm{mmol})$, 4-hydroxycoumarin $(2.0 \mathrm{mmol})$ in the presence of various catalysts (Table 4). As revealed in Table 4, SA might function as an efficient catalyst with respect to the reaction time and yield. The important benefits of this approach are shorter reaction times, simple work-up process, cheap and non-toxic catalysis, easy preparation and handling of the catalyst, environmental benignity, reprocessing of the catalyst and outstanding yields. 


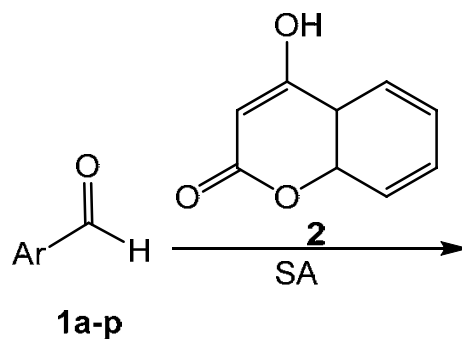<smiles>O=C1Oc2ccccc2C(=O)C1C(O)Br</smiles><smiles>O=C1Oc2ccccc2C(=O)C1=CBr</smiles>

8

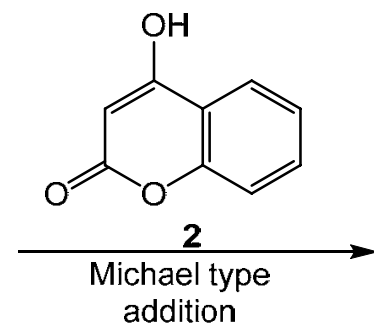<smiles>O=C1Oc2ccccc2C(=O)C1C(Br)c1c(O)c2ccccc2oc1=O</smiles>

\section{Tautomerization}<smiles>O=c1oc2ccccc2c(O)c1C(Br)c1c(O)c2ccccc2oc1=O</smiles>

3a-p

Scheme 3 - A proposed mechanism for the formation of biscoumarins.

Table 4

Comparison of the catalytic performance of SA catalyst for the synthesis of $3 \mathrm{e}$ with those obtained by reported catalysts

\begin{tabular}{|c|c|c|c|c|}
\hline Entry & Catalyst (mol\%) & Solvent/Temp & Time (min) & $\%$ Yield $^{\text {ref. }}$ \\
\hline 1 & sulfanilic acid (SA) (10) & $\mathrm{H}_{2} \mathrm{O} / 80^{\circ} \mathrm{C}$ & $25 \mathrm{~min}$ & $98^{[\text {this work }]}$ \\
\hline 2 & {$\left[\mathrm{P}_{4} \mathrm{VPy}-\mathrm{BuSO}_{3} \mathrm{H}\right] \mathrm{HSO}_{4}(10)$} & Toluene $/ 90{ }^{\circ} \mathrm{C}$ & $42 \mathrm{~min}$ & $95^{28}$ \\
\hline 3 & sulfosalicylic acid (15) & $\mathrm{H}_{2} \mathrm{O} / 80{ }^{\circ} \mathrm{C}$ & $28 \mathrm{~min}$ & $95^{29}$ \\
\hline 4 & Nano-MgO (3) & None $/ 100^{\circ} \mathrm{C}$ & $21 \mathrm{~min}$ & $88^{30}$ \\
\hline 5 & Sodium dodecyl sulfate(SDS) (20) & $\mathrm{H}_{2} \mathrm{O} / 60^{\circ} \mathrm{C}$ & $147 \mathrm{~min}$ & $95^{14}$ \\
\hline 6 & $\mathrm{SiO}_{2} \mathrm{Cl}(75)$ & $\mathrm{CH}_{2} \mathrm{Cl}_{2} / 40{ }^{\circ} \mathrm{C}$ & $210 \mathrm{~min}$ & $90^{31}$ \\
\hline 7 & PISA (10) & $\mathrm{H}_{2} \mathrm{O}: \mathrm{EtOH}(1: 1) / 80{ }^{\circ} \mathrm{C}$ & $30 \mathrm{~min}$ & $96^{24}$ \\
\hline 8 & Poly(4-vinylpyridinium)perchlorate (30) & $\mathrm{H}_{2} \mathrm{O} / 80^{\circ} \mathrm{C}$ & $15 \mathrm{~min}$ & $91^{26}$ \\
\hline
\end{tabular}

${ }^{\mathrm{a}}$ Reaction conditions: 3-Nitro-benzaldehyde (1.0 mmol), 4-hydroxycoumarin (2.0 mmol). ${ }^{\mathrm{b}}$ Isolated yields

\section{EXPERIMENTAL}

\section{Materials}

All the reagents and chemicals were commercially available and used without further purification. All yields refer to the isolated products. The known products were identified by comparison of their melting points and spectral data with those reported in the literature.

\section{Equipment}

The progress of the reactions was monitored by TLC on Merck pre-coated silica gel 60 F254 aluminum sheets, visualized by UV light. IR spectra were recorded on a Shimadzu FT-IR 8300 Spectrophotometer using the $\mathrm{KBr}$ pellets technique. ${ }^{1} \mathrm{H}$ NMR and ${ }^{13} \mathrm{C}$ NMR spectra were recorded at ambient temperature on a BRUKER AVANCE
DRX-500 MHz spectrophotometer using DMSO-d6 as the solvent and TMS as an internal standard.

\section{Procedure}

A mixture of 4-hydroxycoumarin $(2.0 \mathrm{mmol})$, aldehyde $(1.0 \mathrm{mmol}), \mathrm{SA}(0.017 \mathrm{gr}, 10 \mathrm{~mol} \%)$, and water $(5.0 \mathrm{~mL})$ in a round bottom flask was heated at $80{ }^{\circ} \mathrm{C}$ for the appropriate time as mentioned in Table 2. After the completion of the reaction (monitored by TLC), the reaction mixture was cooled to room temperature. Then, the precipitated product was filtered, washed with water $(20 \mathrm{~mL})$ and ether $(10 \mathrm{~mL})$, and dried in vacuum to give the pure targeted compounds $\mathbf{3 a}-\mathbf{p}$ in high yields. The catalyst was recovered from the filtrate by evaporation of the water in vacuo. The residue was then washed with ethyl acetate ( 3 times, $3.0 \mathrm{~mL}$ ), dried, and reused for the next runs. The catalyst was successfully reused up to five runs without significant decrease of the yields. All 
products were characterized by IR, ${ }^{1} \mathrm{H}$ and ${ }^{13} \mathrm{C}$ NMR spectral data and by comparison with melting points of the reported compounds.

\section{Spectral data of some selected products:}

3, 3'-((4-Methoxyphenyl)methylene)bis (4-hydroxy-2Hchromen-2-one) (3h)

IR (KBr): 3440, 3072, 3002, 1668, 1604,1565, 1510,1454, 1353, 1258, 1180, 1094, 907, 828, $768 \mathrm{~cm}^{-1}$; ${ }^{1} \mathrm{H}$ NMR (500 MHz, DMSO-d6): $\delta 3.81(\mathrm{~s}, 3 \mathrm{H}), 6.05(\mathrm{~s}, 1 \mathrm{H}), 6.89(\mathrm{~d}$, $\mathrm{J}=8.7 \mathrm{~Hz}, 2 \mathrm{H}), 7.14(\mathrm{~d}, \mathrm{~J}=8.7 \mathrm{~Hz}, 2 \mathrm{H}), 7.31-7.42(\mathrm{~m}, 4 \mathrm{H})$, $7.65(\mathrm{t}, \mathrm{J}=8.2 \mathrm{~Hz}, 2 \mathrm{H}), 8.02(\mathrm{dd}, \mathrm{J}=8.4 \mathrm{~Hz}, 2 \mathrm{H}), 11.31$ (s, $1 \mathrm{H}), 11.53$ (s, $1 \mathrm{H})$; Anal. Calcd. For $\mathrm{C}_{26} \mathrm{H}_{18} \mathrm{O}_{7}$ : C, 70.58; $\mathrm{H}$, $4.10 \%$; found $\mathrm{C}, 70.48 ; \mathrm{H}, 4.21 \%$.

\section{3, 3'-((4-Chlorophenyl)methylene)bis(4-hydroxy-2H-} chromen-2-one) (3f)

IR (KBr): 3352, 3069, 2680, 2610, 1669, 1619, 1600, 1491, 1455, 1353, 1310, 1267, 1185, 1096, 922, 910, 822, $790 \mathrm{~cm}^{-1}$; ${ }^{1} \mathrm{H}$ NMR (500 MHz, DMSO-d6): $\delta 6.08(\mathrm{~s}, 1 \mathrm{H})$, $7.19(\mathrm{dd}, \mathrm{J}=0.9,8.5 \mathrm{~Hz}, 2 \mathrm{H}), 7.32(\mathrm{~d}, \mathrm{~J}=8.6 \mathrm{~Hz}, 2 \mathrm{H}), 7.41$ $7.46(\mathrm{~m}, 4 \mathrm{H}), 7.66-7.69(\mathrm{~m}, 2 \mathrm{H}), 8.03(\mathrm{~d}, \mathrm{~J}=7.8 \mathrm{~Hz}, 1 \mathrm{H}), 8.11$ $(\mathrm{d}, \mathrm{J}=7.74 \mathrm{~Hz}, 1 \mathrm{H}), 11.37(\mathrm{~s}, 1 \mathrm{H}), 11.59(\mathrm{~s}, 1 \mathrm{H}) ;{ }^{13} \mathrm{C} \mathrm{NMR}$ (125MHz, DMSO-d6): $\delta 36.2,104.1,105.7,116.8,117.0$, 117.1, 117.2, 124.8, 125.4, 128.4, 129.2, 133.1, 133.5, 134.3, 152.7, 152.9, 165.1, 166.4, 167.3, 169.6; Anal. Calcd. For $\mathrm{C}_{25} \mathrm{H}_{15} \mathrm{ClO}_{6}$ : C, 67.20; H, 3.38\%; found C, 67.18; H, 3.42\%.

\section{(5)}

3,3'-(propane-1,1-diyl)bis(4-hydroxy-2H-chromen-2-one)

IR (KBr): 3373, 3066, 2621，1673，1626，1605, 1467, 1323, 1311, 1266, $11751096,1034 \mathrm{~cm}^{-1}$; ${ }^{1} \mathrm{H}$ NMR $(500 \mathrm{MHz}$, DMSO-d6): $\delta 0.89$ (t, J = 6.1,3H), $1.55(\mathrm{qd}, \mathrm{J}=6.1,5.4,2 \mathrm{H})$, $4.39(\mathrm{t}, \mathrm{J}=5.4 \mathrm{~Hz}, 2 \mathrm{H}), 7.23-7.28(\mathrm{~m}, 2 \mathrm{H}), 7.35-7.43(\mathrm{~m}, 4 \mathrm{H})$, 7.56-7.61 (m, 2H), $7.93(\mathrm{~d}, \mathrm{~J}=7.5 \mathrm{~Hz}, 1 \mathrm{H}), 8.17(\mathrm{~d}, \mathrm{~J}=7.9 \mathrm{~Hz}$, $1 \mathrm{H}), 11.78(\mathrm{~s}, 1 \mathrm{H}), 12.27(\mathrm{~s}, 1 \mathrm{H}) ;{ }^{13} \mathrm{C} \mathrm{NMR}(125 \mathrm{MHz}$, DMSO-d6): $\delta 10.8,17.6,30.3,101.1,103.5,118.3,119.5$, $120.1,121.7,122.8,124.0,126.7,127.1,130.1,130.9,149.8$, $151.1,152.9,166.8,167.2,169.1,171.4$; Anal. Calcd. For $\mathrm{C}_{21} \mathrm{H}_{16} \mathrm{O}_{6}$ : C, 69.23; H, 4.43\%; found C, 69.37; H, 4.29\%.

\section{CONCLUSIONS}

In conclusion, SA was found to be as a novel and efficient catalyst for the synthesis of biscoumarine derivatives under aqueous media. We have developed an environmentally benign catalytic method for the synthesis of biscoumarins through the reaction of various aldehydes with 4hydroxycoumarin. This method offers several advantages, including high yield of products, short reaction time, low cost, cleaner reaction profile, ease of preparation of catalyst, and ease of work up. Additionally, the catalyst was successfully recovered and recycled for at least five runs without significant loss in activity.

Acknowledgment: Financial support of Islamic Azad University, South Tehran Branch is acknowledged.

\section{REFERENCES}

1. M. Seddighi, F. Shirini and M. Mamaghani, RSC Adv., 2013, 3, 24046. DOI 10.1039/c3ra44053b.

2. N. Tavakoli-Hoseini, M. M. Heravi, F. F. Bamoharram, A. Davoodnia and M. Ghassemzadeh, J. Mol. Liq., 2011, 163, 122-127. DOI:10.1016/j.molliq.2011.08.007.

3. G. Appendino, G. Cravotto, S. Tagliapietra, S. Ferraro, G. M. Nano and G. Palmisano, Helv Chim Acta., 1999, 74, 1451-458. DOI 10.1002/hlca.19910740708.

4. Y. Kong, Y. Fu, Y. Zu, F. Chang, Y. Chen, X, Lio, J. Stelten and H. Schiebel, Food Chem., 2010, 121, 11501155. DOI 10.1016/j.foodchem.2010.01.062.

5. J. Neyts, E. D. Clercq, R Singha, Y. H. Chang, A. R. Das, S. K. Chakraborty, S. C. Hong, S. C. Tsay, M. Hsu and J. R. Hwu, J. Med. Chem., 2009, 52, 1486-1490. DOI 10.1021/jm801240d.

6. C. Ito, M. Itoigawa, S. Onoda, A. Hosokawa, N. Ruangrungsi, T. Okuda, H. Tokuda, H. Nishino and H. Furukawa, Phytochemistry., 2005, 66, 567-572. DOI 10.1016/j.phytochem.2004.12.030.

7. S. S. Bhattacharyya, S. Paul, S. K. Mandal, A. Banerjee, N. Boujedaini and A. R. Khuda-Bukhsh, Eur. J. Pharmacol., 2009, 614, 128-136. DOI 10.1016/j.ejphar. 2009.04.015

8. H. Hussain, J. Hussain, A. Al-Harrasi and K. Krohn, Tetrahedron, 2012, 68, 2553-2573.

9. D. Završnik, S. Muratović, D. Makuc, J. Plavec, M. Cetina, A. Nagl, E. D. Clercq, J. Balzarini and M. Mintas, Molecules, 2011, 16, 6023-6040. DOI 10.3390/molecules 16076023 .

10. C. X. Su, J. F. Mouscadet, C. C. Chiang, H. J. Tsai and L.Y Hsu, Chem. Pharm. Bull., 2006, 54, 682-686. DOI 10.1248/cpb.54.682.

11. M. Kidwai, V. Bansal, P. Mothsra, S. Saxena, R..K. Somvanshi, S. Dey and T..P. Singh, J. Mol. Catal. A: Chem., 2007, 268, 76-81. DOI 10.1016/j.molcata. 2006.11.054.

12. J.M. Khurana and S. Kumar, Tetrahedron Lett., 2009, 28, 4125-4127. DOI 10.1016/j.tetlet.2009.04.125.

13. B. Karmakar, A. Nayak and J. Banerji, Tetrahedron Letters., 2012, 53, 4343-4346. DOI 10.1016/j.tetlet. 2012.06.024.

14. H. Mehrabi and H. Abusaidi, J. Iran. Chem., 2010, 7, 890-894.

15. W. Li, Y. Wang, Z. Wang, L. Dai and Y. Wang, Catalysis Letters., 2011, 141, 1651-1658.

16. Z. Siddiqui and F. Farooq, Catal. Sci. Technol., 2011, 1, 810-816. DOI: $10.1039 / \mathrm{C} 1 \mathrm{CY} 00110 \mathrm{H}$.

17. J. M. Khurana and S. Kumar, Monatshefte für Chemie/Chemical Monthly., 2010, 141, 561-564.

18. K. Tabatabaeian, H. Heidari, A. Khorshidi, M. Mamaghani and N. O. Mahmoodi, J. Serb. Chem. Soc., 2012, 77, 407-567. DOI: $10.2298 /$ JSC110427189T.

19. B. Sadeghi and T. Ziya, J. Chem., 2013, 1-5. DOI 10.1155/2013/179013.

20. V. Padalkar, K. Phatangare, S. Takale, R. Pisal and A. Chaskar, J. Saudi Chem. Soc., 2015, 19, 42-45. DOI 10.1016/j.jscs.2011.12.015.

21. A. Zhu, S. Bai, L. Li, M. Wang and J. Wang, Catal. Lett., 2015, 145, 1089-1093.

22. J. Albadi, A. Mansournezhad and S. Salehnasab, Res. Chem. Intermed., 2015, 41, 5713-5721.

23. M. Faisal, F. A. Larik and A. Saeed, J. Porous Mater., 2019, 2, 455-466. 
24. H. Kiyani, H. Darbandi and M. Tazari, Jordan J. Chem., 2016, 11, 77-84.

25. S. K. Patil, D. V. Awale, M. M. Vadiyar, S. A. Patil, S. C. Bhise, S. S. Kolekar, Res. Chem. Intermed., 2017, 43, 5365-5376. DOI 10.1007/s11164-017-2932-5.

26. J. Meinwald, S. S. Labana and M. S. Chadha, J. Am. Chem. Soc., 1963, 85, 582-585. DOI 10.1021/ ja00888a022

27. R. Rezaei, F. Moezzi and M. M. Doroodmand, Chin. Chem. Lett., 2014, 25, 183-186. DOI 10.1016/j.cclet. 2013.10.033.
28. K. Parvanak Boroujeni, P. Ghasemi and Z. Rafienia, Monatsh. Chem., 2014, 145, 1023-1026. DOI 10.1007/s00706-014-1156-2.

29. H. Kiyani and H. Darbandi, Chiang Mai J. Sci., 2017, 44, 1002-1010.

30. J. Safaei-Ghomi, F. Eshteghal and M. A. Ghasemzadeh, Acta Chim. Slo., 2014, 61, 703-708.

31. F. Shirini, S. Esmaeeli Ranjbar and M. Seddighi, Chin. J. Catal., 2014, 35, 1017-1023. DOI 10.1016/S1872-2067 (14)60061-9. 